\title{
Současný areál výskytu mývala severního (Procyon lotor) v České republice dle odlovu (Carnivora: Procyonidae)
}

\section{Vendula LIPŠOVÁ \& Oldřich KOPECKÝ}

Katedra zoologie a rybářství, Fakulta agrobiologie, potravinových a přírodních zdrojů, Česká zemědělská univerzita, Kamýcká 129, 16521 Praha-Suchdol; kopeckyo@af.czu.cz

došlo 24. února 2021

Current range of Procyon lotor in the Czech Republic based on hunting statistics (Carnivora: Procyonidae). The common raccoon (Procyon lotor), introduced to Europe at the end of the first half of the 20th century, is included in the EU Black List of Invasive Alien Species. Due to its assessed high impact on the European biodiversity, research has been focused on the specific influence of its introduction and evaluating the intensity and direction of its invasion. In the Czech Republic, two separate raccoon populations are known - in northwestern Bohemia and central and southern Moravia. We used the bag records from the Annual reports on hunting grounds, game numbers and game huntings at the level of municipalities with extended competences (ORP) for the retrospective assessment of the raccoon distribution in the Czech Republic. The reports from the hunting years 2011/2012 to 2017/2018 were evaluated. In the first year (2011/2012), 234 individuals were caught in 23 ORP (out of a total of 205 ORP of the country). In the last year of the evaluation (2017/2018), 1,352 individuals were caught in 56 ORP. The highest density of the Bohemian population was recorded in the hunting year 2017/2018 (0.45 individuals per 100 hectares) in the Karlovy Vary ORP. In the Moravian population, the peak was reached in the hunting year 2013/14, when 0.59 individuals per 100 hectares were recorded in the Přelouč ORP.

Key words. Invasion, alien species, distribution, mammal, monitoring, hunting.

\section{ÚVOD}

Výskyt řady nepůvodních druhů př́ímo souvisí s činností člověka, především s globalizací, urbanizací a návaznou poptávkou po zájmovém chovu živočichů a pěstování okrasných rostlin (např. JeschKe \& StraYER 2005, RichARDSON \& PyŠEK 2006, NenTwig et al. 2010). Nepůvodní druhy, pokud se jim podaří v novém prostředí usadit a následně šírit, a které působí negativní změny v místních ekosystémech, jsou označovány za invazní (MACK et al. 2000).

Na tuto situaci reagují s určitým zpožděním i legislativní nástroje. V roce 2014 bylo pro území EU vydáno nařízení Evropského parlamentu a Rady Evropské unie č. 1143/2014 o prevenci a regulaci zavlékání či vysazování a šíření invazních nepůvodních druhů (EU 2014). V návaznosti byl vytvořen seznam nepůvodních invazních druhů s významným dopadem na přírodu EU (“unijní seznam”), trrídící invazní druhy do tří kategorií, kdy nejvíce rizikové druhy jsou zařazené na tzv. černý seznam. Na černém seznamu je uveden též mýval severní, Procyon lotor (Linnaeus, 1758). 
Mýval severní je původní v Severní a Střední Americe, kde je jeho typickým biotopem mozaika zalesněných a otevřených prostředí (BEASLEY et al. 2007, CHAMBERLAIN et al. 2007). Velmi úspěšně se také přizpůsobil životu poblíž lidských sídel a v člověkem pozměněné krajině (GERTH 2003). Mýval severní je omnivorní potravní oportunista. Loví korýše (Crustacea), měkkýše (Mollusca), obojživelníky (Amphibia), plazy (Reptilia), ptáky (Aves), hmyz (Insecta) i ryby (Osteichthyes). Vybírá ptačí i plazí hnízda, konzumuje zemědělské plodiny a jako doplňkový zdroj potravy využívá odpadky (Zeveloff 2002, Prange et al. 2004, PARSONS et al. 2013). Krom možného přenosu nemocí nejen na člověka, ale i na volně žijící zviřrata (Roscoe 1993, KaZACOS 2001, Blanton et al. 2007), spočívá jeho nebezpečnost zejména v predaci ohrožených živočichů a v potravní konkurenci domácím druhům volně žijících šelem (Musıloví et al. 2011, ANDĚra \& GAISLER 2012).

Do Evropy byl mýval severní introdukován v první polovině 20. století, a to do Německa, Běloruska a oblasti Kavkazu (Aliev \& SANDERSon 1966, Lutz 1995). Fisher et al. (2017) předpokládají, že v Německu došlo nejméně ke čtyřem samostatným introdukcím. Důvodem pro introdukci mývala do Evropy bylo obohacení honiteb o nové lovné kožišinové zvíře. Populace mývalů v nových územích se také nekontrolovaně posilovaly o jedince uniklé z kožešinových farem (BIEDRZYCKA et al. 2014). V Evropě byl jeho výskyt doposud potvrzen v Irsku, Spojeném království, Španělsku, Francii, Švýcarsku, Itálii, Srbsku, Bosně a Hercegovině, Rumunsku, Mad'arsku, Slovensku, Rakousku, České republice, Polsku, Dánsku, Norsku, Švédsku, Litvě, Estonsku, Ukrajině, Bělorusku a na jihozápadě Ruska (StubBe 1999, Hohmann et al. 2001, BeltráN-Beck et al. 2012, SAlgado 2018). Na území Čech docházelo během 20. století ke sporadickým záznamům výskytu mývalů. Tito mývalové pocházeli ze zájmových a farmových chovů, ale nevytvořili stálou populaci (ANDĚRA \& HANZAL 1996).

V současnosti je v ČR mýval severní stabilně rozšířen ve dvou doposud navzájem izolovaných populacích. Jedna z mývalích populací v povodí řeky Moravy se etablovala ve druhé polovině 90. let 20. století v důsledku šírení rakouské populace na sever (SACKL 2001). Rozrůstající se populace v západních a severozápadních Čechách má zase svůj původ na území Německa (ČERVENÝ et al. 2001, ANDĚRA \& ČERVENÝ 2009, MATĚJŮ et al. 2012). K prvnímu odlovu mývala na území ČR došlo v mysliveckém roce 2003/2004 (ÚHÚL 2020). Vzhledem k tomu, že dochází k územnímu šíření mývala a ke zvyšování početnosti odlovených jedinců (MATĚJư et al. 2012, ÚHÚL 2020), jsme se rozhodli zmapovat rozšíření mývala severního v ČR a popsat postupné změny početnosti tohoto druhu $\mathrm{v}$ čase a prostoru.

\section{METODIKA}

Dlouhodobá evidence je $\mathrm{k}$ dispozici ve veřejné nálezové databázi na webovém serveru biolib.cz a na stránkách Agentury ochrany př́rody a krajiny ČR (http://invaznidruhy.nature.cz/). Studie zaměřené čistě na výskyt mývala severního jsou ojedinělé (MATĚJư et al. 2012), většinou bývá popisován v rámci širší faunistické analýzy konkrétního území (MuSILOvá et al. 2011, ANDĚra \& GAISLER 2012, KuTAL et al. 2016).

Nejsystematičtější data o trendech výskytu lze získat z myslivecké statistiky úlovků neboli Ročních výkazů o honitbách, stavu a lovu zvěre. Ty jsou každoročně vyplňovány členy mysliveckých sdružení za každou honitbu zvlášt' a tato data jsou dále zpracovávána státní správou. Veřejně př́ístupná je databáze na stránkách Ústavu hospodářské úpravy lesů (ÚHÚL 2020) pomocí aplikace SIL. Zde jsou k dispozici souhrnné výkazy jak za celou Českou republiku, tak i za jednotlivé kraje, okresy i obce s rozš́írenou působností (ORP). Pro účely této práce byly použity výkazy za ORP jakožto nejmenší územní jednotky.

Na území ČR je v současnosti vymezeno 205 území ORP. Nejvíce území ORP je ve Středočeském kraji (26) a nejméně naopak v Karlovarském kraji (7). Území ORP mají velmi rozdílnou rozlohu od $44 \mathrm{~km}^{2}$ (ORP Český Těšín) do 1.242 km² (ORP Znojmo). Kvůli velkým rozdílům v rozloze byla pro porovnání 
výskytu mývala na jednotlivých územích ORP zvolena přepočtená hodnota počtu zaznamenaných jedinců na 100 ha. Zpracovány byly údaje od 1. dubna 2011 do 31. března 2018, tj. za sedm “mysliveckých" roků. Starší záznamy nejsou veřejně dostupné.

Mapové zpracování bylo provedeno pomocí programu QGIS 3.10 (Geografical Information Systems) $\mathrm{s}$ využitím údajů ESRI. Přes relativně velké rozdíly v rozloze jednotlivých území ORP a časté nízké počty zaznamenaných úlovků nebyly žádné údaje vynechány. Pro zpracování kartogramů byly údaje uspořádány do následujících osmi tříd dle počtu nahlášených jedinců na 100 ha: (a) žádný výskyt, 0; (b) velmi řídký výskyt, 0,0001-0,001 jedinců na 100 ha; (c) řídký výskyt, 0,0011-0,005 jedinců na 100 ha; (d) občasný výskyt, 0,0051-0,01 jedinců na 100 ha; (e) častý výskyt, 0,011-0,05 jedinců na 100 ha; (f) velmi častý výskyt, $0,051-0,1$ jedinců na 100 ha; (g) vysoký výskyt, $0,11-0,5$ jedinců na 100 ha; (h) velmi vysoký výskyt, $0,51-1,0$ jedinců na 100 ha.

\section{VÝSLEDKY}

Z celorepublikových údajů jednoznačně vyplývá nárůst počtu mývalů na území ČR: v mysliveckém roce 2011/2012 byl nahlášen úlovek 234 jedinců, zatímco v roce 2017/2018 již 1352 jedinců. Za sedm let došlo $\mathrm{k}$ nárůstu odlovených mývalů téměř šestinásobně (obr. 1). Alespoň jednou byl ulovený mýval severní ve sledovaných letech vykázán ve 118 ORP, přičemž rozloha území těchto ORP činí 68,25 \% území České republiky (obr. 2). Dvacet sedm ORP (20 v severozápadních Čechách a sedm na Moravě) hlásilo odlov mývala kontinuálně ve třech posledních letech (myslivecké roky 2015/2016, 2016/2017 a 2017/2018). Na území těchto ORP lze předpokládat již stabilní výskyt mývala.

Při pohledu na kartogramy ORP s vyznačenou denzitou dle jednotlivých mysliveckých sezón (obr. 3) jsou patrná dvě centra, z nichž se mýval šíří. Prvním centrem je Karlovarský kraj, konkrétně území ORP Karlovy Vary, z něj byl vykázán v mysliveckém roce 2011/2012 úlovek

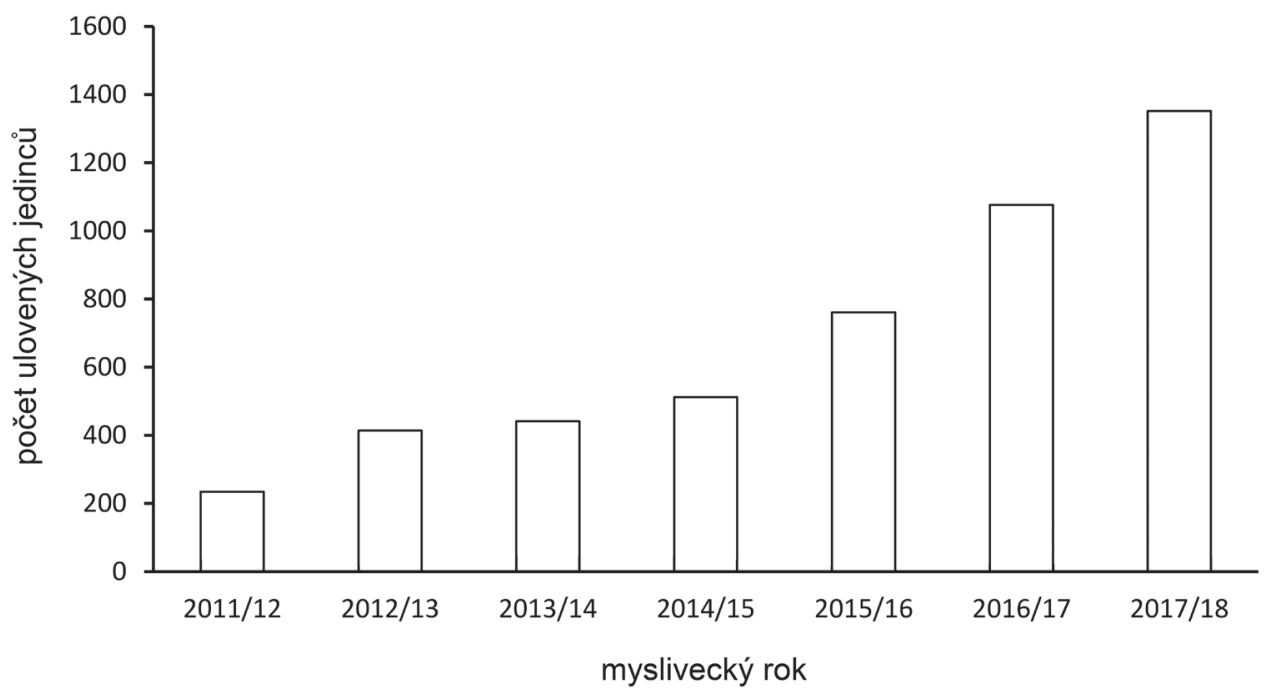

Obr. 1. Počty ulovených jedinců mývala severního (Procyon lotor) v České republice mezi lety 2011 a 2018 podle mysliveckých roků. 


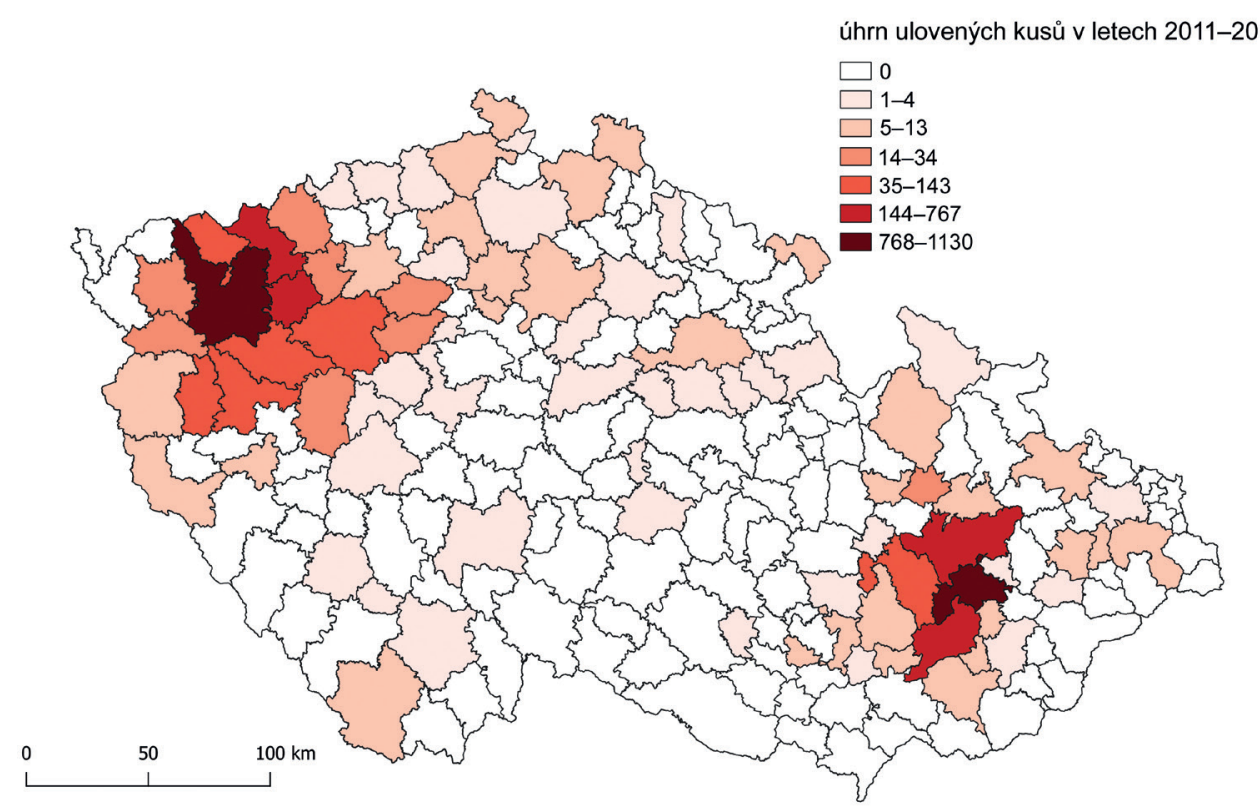

Obr. 2. Celková suma ulovených mývalů severních (Procyon lotor) v České republice v jednotlivých katastrech obcí s rozšířenou působností mezi lety 2011 a 2018 podle mysliveckých roků.

12 mývalů (denzita 0,01 jedince na 100 ha) ovšem v roce 2017/2018 již 535 jedinců (denzita 0,45 jedinců na 100 ha). Z tohoto centra postupuje šíření mývala všemi směry.

Druhým centrem je území ORP Přerov v Olomouckém kraji. Zde bylo nejvyšší denzity, tj. 0,59 mývala na 100 ha, dosaženo v mysliveckém roce 2012/2013. Situace se v posledním roce sledování $(2017 / 2018)$ zlepšila a mývalů oproti vrcholu ubylo - 0,18 jedince na 100 ha. Zároveň je ze srovnání patrné, že šíření do území přilehlých ORP je mnohem pozvolnější než v Čechách, a to i přesto, že na počátku sledovaného období (tj. v mysliveckém roce 2011/2012) byla v ORP Přerov denzita mývalů nejvyšší v rámci celé ČR.

\section{DISKUSE}

Námi zpracované údaje jednoznačně ukazují zvyšující se početnost ulovených jedinců mývala na území ČR. Na území některých ORP se jedná jen o sporadické zástřely (např. v kraji Vysočina), avšak obzvláště v Olomouckém, Karlovarském, Ústeckém a také Plzeňském kraji je patrna přítomnost etablovaných populací s vysokou denzitou. Hlášení úlovků ukazují, že došlo k úspěšné introdukci i mimo severozápadočeskou a moravskou populaci, taková situace je známa např. z území ORP Frýdlant, ORP Opava, ORP Mladá Boleslav a ORP Mělník.

V oblasti původního výskytu mývala severního je běžná populační denzita 10-12 jedinců na 100 ha (KAUFMANN 1982, ZEVELOFF 2002), avšak v zemědělských a urbanizovaných oblastech může vzrůst až na 333 jedinců na 100 ha (GEHRT \& Fritzell 1998, RILEY et al 1998). V nepů- 
vodních oblastech je denzita populací nižší - dosud nejvyšší je známa v Německu, v NP Müritz (severovýchodní Německo) bylo v roce 2010 šest až osm mývalů na 100 ha (MuschIK et al. 2011) a na okraji města Bad Karlshafen ve středním Německu pak až 100 jedinců na 100 ha (Hohmann \& BARTUSSEK 2011).

Zvláštní pozornost je třeba věnovat lesním a břehovým ekosystémům s výskytem mývala severního, nebot' tam vytváŕí predační tlak na ohrožené obojživelníky, plazy a raky (MusiLová et al. 2011, ANDĚra \& GAISLER 2012). Překryv výskytu mývala a jeho možný negativní vliv byl diskutován u jedné z populací kriticky ohrožené užovky stromové (Zamenis longissimus; MusıLoví et al. 2011). Z ČR zatím predace raků mývalem popsána nebyla, v Itálii však byla potvrzena predace původního a chráněného raka bledonohého (Austropotamobius pallipes; BosCHERINI et al. 2019). V Evropě byla dále zaznamenána predace mývalem vajec sladkovodní želvy bahenní (Emys orbicularis; SCHNEEWEISS \& WoLF 2009), v ČR též kriticky ohrožené.

Vzhledem k značnému nárůstu početnosti a též rychlé územní expanzi je třeba věnovat mývalu severnímu zvýšenou pozornost. Ačkoliv např̀ ve srovnání s Německem je denzita jeho populací na území ČR nižší a nejsou prozatím hlášeny systematické problémy působené touto šelmou, je třeba zejména zabránit situaci, kdy by došlo k propojení obou doposud izolovaných populací mývalů. K nárůstu početnosti i rozšiřování areálu v Německu, a potažmo jinde v Evropě, došlo totiž právě po propojení do té doby izolovaných populací ze středního a severovýchodního Německa v devadesátých letech 20. století (Frantz et al. 2013, FisHER et al. 2015).
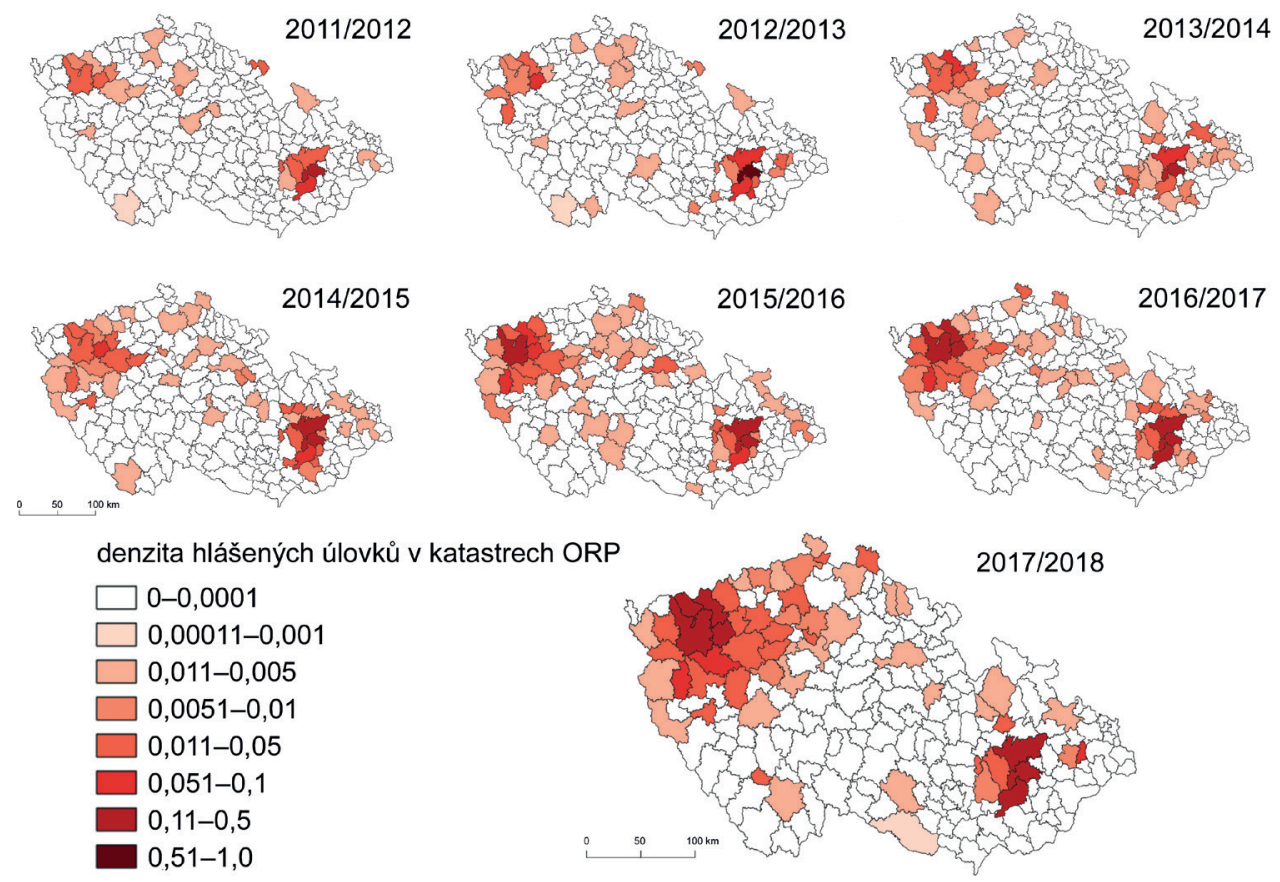

Obr. 3. Denzita (počet jedinců/100 ha) ulovených mývalů severních (Procyon lotor) v jednotlivých katastrech obcí s rozšířenou působností (ORP) mezi lety 2011 a 2018 podle mysliveckých roků. 
Snaha státní ochrany přírody by tedy měla být zaměřena právě na oblasti, kde hrozí propojení populací. Předpokládáme, že takovouto oblastí se může v budoucnu stát Pardubický kraj. Pokud se nezmění směr invaze moravské populace, která prozatím probíhá povodími řeky Moravy a jejích přítoků, a česká populace se bude i nadále šírit podél řeky Labe a případně jejího přítoku Orlice, pak je reálné riziko propojení těchto populací na českomoravském pomezí na východě Pardubického kraje.

Sledování mývala severního je v ČR prozatím praktikováno převážně náhodnými pozorováními. Tato “metoda” sice není nijak standardizovaná, ale získaná data jsou vhodná k doplnění Nálezové databáze AOPK ČR (PolEDNíK \& PoledNíková 2010). Nejčastěji bývají zaznamenány pobytové znaky (otisky choditel, trus), fotografie z fotopastí, kadávery přejetých jedinců a odchyty do živochytných pastí (MinÁrIKová et al. 2015a, b, FIDERER et al. 2019, ScHWARTZ et al. 2020).

Zpracování mysliveckých statistik úlovků je metodou nepř́mého měření populační denzity a dynamiky populace (BROOK \& BRADSHAw 2006). Ačkoliv výkazy z honiteb nemusí být zcela spolehlivé (špatná determinace druhu, nepravdivě vyplněné výkazy, změny plochy honiteb, změny členů sdružení vyplňujících výkazy nebo jiná strategie odlovu druhu), mohou přesto sloužit k vyhodnocování dlouhodobých trendů vývoje populačních změn (CATTADORI et al. 2003, CARLSSON et al. 2010). Výhodou mysliveckých výkazů z honiteb je nezkreslenost v podobě sledování celého území ČR či naopak pouze zvláště chráněných území, a proto v současnosti údaje z nich pro daný druh považujeme za dostatečně relevantní.

Dle našeho názoru by bylo vhodné zintenzivnit spolupráci se členy zájmových spolků a sdružení, především mysliveckých a rybářských. Z naší práce je možné získat představu o celkové situaci a s ní dále pracovat - zaměřit se na ohniska populací, kde je třeba zintenzivnit regulaci druhu; vytipovat oblasti, kde může dojít ke konfliktu s ohroženými druhy původní fauny; upozornit na směr expanze populace myslivce v okolních oblastech, apod. Důležitá je též spolupráce s laickou veřejností a celkově zlepšení osvěty o nezbytnosti regulace nepůvodních populací mývala severního.

\section{PODĚKOVÁNÍ}

Na tomto místě bychom rádi poděkovali Markovi ČELONKOvi za nepostradatelnou pomoc s kartografickými výstupy. Dále zaměstnancům ÚHÚL v Brandýse nad Labem-Staré Boleslavi, kteří v prosinci 2019 přispěli k finální podobě zpracování dat, speciálně Leoši MACKOVI. Také těm zaměstnancům státní správy, kteří si vyhradili čas ke konzultacím a k poskytnutí informací o úlovcích mývala v jednotlivých honitbách.

\section{LITERATURA}

Aliev F. F. \& Sanderson G. C., 1966: Distribution and status of the raccoon in the Soviet Union. Journal of Wildlife Management, 30: 497-502.

ANDĚRA M. \& ČERVENÝ J., 2009: Velcí savci v České republice. Rozšírení, historie a ochrana. 2. Šelmy (Carnivora). Národní muzeum, Praha, 216 pp.

ANDĚra M. \& GAISLER J., 2012: Savci České republiky: popis, rozšiření, ekologie, ochrana. Academia, Praha, 285 pp.

Anděra M. \& Hanzal V., 1996: Atlas rozšiřeni savců v České republice. Předběžná verze. II. Šelmy (Carnivora). Národní muzeum, Praha, 85 pp.

Beasley J. C., DeVault T. L. \& Rhodes O. E., 2007: Home-range attributes of raccoons in a fragmented agricultural region of northern Indiana. Journal of Wildlife Management, 71: 844-850.

Beltrán-Beck B., García F. J. \& Gortazar C., 2012: Raccoons in Europe: disease hazards due to the establishment of an invasive species. European Journal of Wildlife Research, 58: 5-15. 
Biedrzycka A., Zalewski A., Bartoszewicz M., Okarma H. \& Jędrzejewska E., 2014: The genetic structure of raccoon introduced in Central Europe reflects multiple invasion pathways. Biological Invasions, 16: 1611-1625.

Blanton J. D., Hanlon C. A. \& Rupprecht C. E., 2007: Rabies surveillance in the United States during 2006. Journal of the American Veterinary Medical Association, 231: 540-556.

Boscherini A., Mazza G. \& Menchetti M., 2019: Time is running out! Rapid range expansion of the invasive northern raccoon in central Italy. Mammalia, 84: 98-101.

Brook B. W. \& Bradshaw C. J. A., 2006: Strenght of evidence for density dependence in abundance time series of 1198 species. Ecology, 87: 1445-1451.

Carlsson N. O., JeschKe J. M., Holmqvist N. \& KindBerg J., 2010: Long-term data on invaders: when the fox is away, the mink will play. Biological Invasions, 12: 633-641.

Cattadori I. M., Haydon D. T., Thirgood S. J. \& Hudson P. J., 2003: Are indirect measures of abundance a useful index of population density? The case of red grouse harvesting. Oikos, 100: 439-446.

Chamberlain M. J., Austin J., Leopold B. D. \& Burger L. W., 2007: Effects of landscape composition and structure on core-use areas of raccoons (Procyon lotor) in a prairie landscape. American Midland Naturalist, 158: 113-122.

ČervenÝ J., AndĚra M., Koubek P., Homolka M. \& Toman A., 2001: Recently expanding mammal species in the Czech Republic: distribution, abundance and legal status. Beiträge zur Jagd- und Wildforschung, 26: 111-125.

EU [Evropská Unie], 2014: Nařízení Evropského parlamentu a Rady (EU) č. 1143/2014 ze dne 22. října 2014 o prevenci a regulaci zavlékání či vysazování a šíření invazních nepůvodních druhů. Úředni Věstník Evropské Unie, 57(L317): 35-55.

Fiderer C., GotTert T. \& Zeller U., 2019: Spatial interrelations between raccoons (Procyon lotor), red foxes (Vulpes vulpes), and ground-nesting birds in a Special Protection Area of Germany. European Journal of Wildlife Research, 65(14): 1-19.

Fisher M. L., Hochkirch A., Heddengott M., Schulze C., Anheyer-Behemenburg H. E., Lang J., Michler F.-U., Hohmann U., Ansorge H., Hoffmann L., Klein R. \& Frantz A. C., 2015: Historical invasion records can be misleading: Genetic evidence for multiple introductions of invasive raccoons (Procyon lotor) in Germany. Public Library of Science One, 10(5; e0125441): 1-17.

Fischer M. L., Salgado I., Beninde J., Klein R., Frantz A. C., Heddergott M. \& Hochkirch A., 2017: Multiple founder effects are followed by range expansion and admixture during the invasion process of the raccoon (Procyon lotor) in Europe. Diversity and Distributions, 23: 409-420.

Frantz A. C., Heddergott M., Lang J., Schulze C., Ansorge H., Runge M. \& Horsburgh G. J., 2013: Limited mitochondrial DNA diversity is indicative of a small number of founders of the German raccoon (Procyon lotor) population. European Journal of Wildlife Research, 59: 665-674.

Gehrt S. D., 2003: Raccoons. Pp.: 611-634. In: Feldhamer G. A., Thompson B. C. \& Chapman J. A. (eds.): Wild Mammals of North America: Biology, Management, and Conservation. Second Edition. The Johns Hopkins University Press, Baltimore, $1232 \mathrm{pp}$.

Gehrt S. D. \& Fritzell E. K., 1998: Resource distribution, female home range dispersion and male spatial interactions: group structure in a solitary carnivore. Journal of Animal Behaviour, 55: 1211-1227.

Hohmann U. \& BartusSeK I., 2011: Der Waschbär. Dritter Edition. Oertel \& Sporer, Reutlingen, 200 pp.

Hohmann U., Voigt S. \& Andreas U., 2001: Quo vadis raccoon? New visitors in our backyards - on the urbanization of an allochthone carnivore in Germany. Pp.: 143-148. In: GotTsCHALK E., BARKow A., Mühlenberg M. \& Settele J. (eds.): Naturschutz und Verhalten: Internationales Symposium am Zentrum für Naturschutz der Universität Göttingen. UFZ-Bericht 2/2001. Helmholz Zentrum für Umweltforschung, Leipzig, $166 \mathrm{pp}$.

JeschKe J. M. \& Strayer D. L., 2005: Invasion success of vertebrates in Europe and North America. Proceedings of the National Academy of Sciences of the United States of America, 102: 7198-7202.

Kaufmann J. H., 1982: Raccoon and allies. Pp.: 567-585. In: Chapman J. A. \& Feldhamer G. A. (eds.): Wild Mammals of North America: Biology, Management and Economics. The John Hopkins University Press, Baltimore, xiii+1147 pp. 
Kazacos K. R., 2001: Baylisascaris procyonis and related species. Pp.: 301-341. In: Samuel W. M., Pybus M. J. \& Kocan A. A. (eds.): Parasitic Diseases in Wild Mammals. Second Edition. Iowa State University Press, Ames, viii +559 pp.

Kutal M., Anděra M., BartoničKa T., Čepelka L., Suchomel J., Dula J. \& Romportl D., 2016: Vyhodnoceni početnosti a mezidruhových vazeb savcù na území NP ČR a analýza vlivu a významu dotčených druhů na ekosystémy vyskytující se v zájmovém území. Certifikovaná metodika. Lesnická a dřevařská fakulta, Mendelova univerzita, $166 \mathrm{pp}$.

LuTz W., 1995: Occurrence and morphometrics of the raccoon (Procyon lotor L.) in Germany. Annales Zoologici Fennici, 32: 15-20.

Mack R. N., Simberloff D., Lonsdale W. M., Evans H., Clout M. \& Bazzaz F. A., 2000: Biotic invasions: causes, epidemiology, global consequences and control. Ecological Applications, 10: 689-710.

MatěJư J., DvořÁk S., TeJrovský V., BušEK O., JeŽEK M. \& MatĚJů Z., 2012: Current distribution of Procyon lotor in north-western Bohemia, Czech Republic (Carnivora: Procyonidae). Lynx, n. s., 43: 133-140.

Mináriková T., Poledníková K., BufKa L., Belotti E., Romportl D., Dietz S., Pavanello M., Munne S. \& PoledNík L., 2015a: Výskyt středně velkých a velkých lesních savců v jižních a jihozápadních Čechách (Carnivora, Artiodactyla, Lagomorpha). Lynx, n. s., 46: 43-64.

MinÁriková T., Š́ma J., Poledník L., ČAMLík G. \& Poledníková K., 2015b: Návrh opatření snižujících vliv invazních šelem na faunu České republiky. ALKA Wildlife, o.p.s., Peč, 21 pp.

Muschik I., KöHnemann B. \& Michler F. U., 2011: Untersuchungen zur Entwicklung des Raum und Sozialverhaltens von Waschbär-Mutterfamilien (Procyon lotor L.) und dessen jagdrechtliche Relevanz. Beiträge zur Jagd- und Wildtierforschung, 36: 573-585.

Musilová R., AlEXANDER Š. \& JANOUŠEK K., 2011: Mýval severní - vetřelec v Poohří. Myslivost, 59: 2-4.

Nentwig W., Kuhnel E. \& BaCher S., 2010: A generic impact-scoring system applied to alien mammals in Europe. Conservation Biology, 24: 302-311.

Parsons A. W., Simons T. R. \& O'Connell Jr. A. F., 2013: Demographics, diet, movements, and survival of an isolated, unmanaged raccoon Procyon lotor (Procyonidae, Carnivora) population on the Outer Banks of North Carolina. Mammalia, 77: 21-30.

PolEDNík L. \& POLEDNíKová K., 2010: Monitoring, regulace a eradikace norka amerického v České republice - metodická doporučení. ALKA Wildlife, o.p.s., Peč, 30 pp.

Prange S., Gehrt S. D. \& Wiggers E. P., 2004: Influences of anthropogenic resources on raccoon (Procyon lotor) movements and spatial distribution. Journal of Mammalogy, 85: 483-490.

Richardson D. \& PYšEK P., 2006: Plant invasions: merging the concepts of species invasiveness and community invasibility. Progress Physical Geography, 30: 409-431.

Riley S. P., Hadidian J. \& Manski D. A., 1998: Population density, survival, and rabies in raccoons in an urban national park. Canadian Journal of Zoology, 76: 1153-1164.

Roscoe D. E., 1993: Epizootiology of canine distemper in New Jersey raccoons. Journal of Wildlife Diseases, 29: 390-395.

SACKL P., 2001: Waschbär Procyon lotor (Linnaeus, 1758). Pp.: 595-602. In: Spitzernberger F. (ed.): Die Säugetierfauna Österreichs. Bundesministerium für Umwelt und Wasserwirtschaft, Graz, 896 pp.

SAlgado I., 2018: Is the raccoon (Procyon lotor) out of control in Europe?. Biodiversity and Conservation, 27: 2243-2256.

SchneEweiss N. \& Wolf M., 2009: Neozoen - eine neue Gefahr fur die Reliktpopulationen der Europaischen Sumpfschildkrote in Nordostdeutschland. Zeitschrift fur Feldherpetologie, 16: 163-182.

Schwartz A. L. W., Shilling F. M. \& Perkins S. E., 2020: The value of monitoring wildlife roadkill. European Journal of Wildlife Research, 66(18): 1-12.

Stubbe M., 1999: Procyon lotor (Linnaeus, 1758). Pp.: 326-327. In: Mitchell-Jones A. J., Amori G., Bogdanowicz W., Kryštufek B., Reijnders P., Spitzenberger F., Stubbe M., Thissen J. B. M., Vohralík V. \& Zima J. (eds.): The Atlas of European Mammals. Academic Press, London, xi+484 pp.

ÚHÚL [Ústav pro hospodářskou úpravu lesů], 2020: Katalog datových informací. URL: http://www.uhul. cz/mapy-a-data/katalog-datovych-informaci.

Zeveloff S. I., 2002: Raccoons: A Natural History. Smithsonian Books, Washington D. C., 240 pp. 